\title{
Unraveling the biological functions of Smad7 with mouse models
}

\author{
Lu Zhu, Susie Chen and Yan Chen*
}

\begin{abstract}
Smad7 is a key negative regulator of the transforming growth factor $\beta$ (TGF- $\beta$ ) signaling and plays an important role in modulating a large array of biological processes. The physiological actions of Smad7 have been extensively investigated by using various mouse models. These studies have pinpointed numerous important in vivo functions of Smad7, including its activity in early embryonic development, fibrosis of many organs, skin cell differentiation, regulation of immune response and inflammation, tumorigenesis, and metabolic control. As most biological activities modulated by Smad7 are closely related to human disorders, it is anticipated that Smad7 will continue to be an intriguing molecule that will be vigorously investigated in the future to strengthen our understanding about the pathogenesis of human diseases.
\end{abstract}

\section{Introduction}

Members of the transforming growth factor $\beta$ (TGF- $\beta$ ) superfamily play essential roles in many physiological and biological processes including embryonic development, tumorigenesis, immunity, inflammation, and various physiologic courses [1]. The canonical signaling event induced by TGF- $\beta$ superfamily members is initiated by ligand-mediated heteroligomerization of the serinethreonine kinase receptors, which phosphorylate signaling-restricted Smads (R-Smads), such as Smad2/3 for TGF- $\beta$ s and Smad1/5/8 for bone morphogenetic proteins (BMPs). The activated R-Smads then form a heterocomplex with a common Smad (Co-Smad or Smad4) and the complex is translocated into the nucleus, resulting in transcriptional regulation of a broad repertoire of target genes [2,3]. On the other hand, Smad6 and Smad7 fall into the inhibitory Smad (I-Smad) subfamily that contains Smad6, a relatively specific inhibitor for BMP signaling, and Smad7, a general inhibitor for both TGF- $\beta$ / activin signaling and BMP signaling [4-6]. Originally, Smad6 and Smad7 were discovered to be upregulated by shear stress in human vascular epithelium [7]. Smad7 was first reported as an inducible antagonist for TGF- $\beta$ mediated signaling upon TGF- $\beta$ activation [5]. It was

\footnotetext{
* Correspondence: ychen3@sibs.ac.cn

Key Laboratory of Nutrition and Metabolism, Institute for Nutritional Sciences, Shanghai Institutes for Biological Sciences, Graduate School of the Chinese Academy of Sciences, Chinese Academy of Sciences, Shanghai,
} China

(c) 2011 Zhu et al; licensee BioMed Central Ltd. This is an Open Access article distributed under the terms of the Creative Commons Attribution License (http://creativecommons.org/licenses/by/2.0), which permits unrestricted use, distribution, and reproduction in any medium, provided the original work is properly cited. found to stably associate with the TGF- $\beta$ receptor complex and block phosphorylation of Smad2/3 upon TGF- $\beta$ stimulation [5]. Smad7 antagonizes TGF- $\beta$ signaling through multiple mechanisms, such as by interfering with the recruitment of R-Smads upon TGF- $\beta$ /activin activation $[5,8]$, by inducing degradation of TGF- $\beta$ type I receptor after recruitment of E3 ubiquitin ligases [9-11], and by recruiting protein phosphatase 1 (PP1) to the receptor complex via interaction with growth arrest and DNA damage protein 34 (GADD34) [12]. In addition to its inhibitory activity to TGF- $\beta$ /activin signaling, Smad7 was also found to be actively involved in mediating the cross-talk between TGF- $\beta$ signaling with other cellular signaling pathways [13].

Since the identification of Smad7 fourteen years ago, the physiological functions of Smad7 have been uncovered mainly through two lines of studies. Firstly, dysregulation of Smad7 has been demonstrated to be associated with the pathogenesis of many human diseases, including malignancy, scleroderma, and chronic inflammatory bowel disease (IBD). Secondly, various animal models have been used to unravel the physiological activities of Smad7. In this review, we will mainly focus on those discoveries pertinent to the physiological functions of Smad7 by studies using mouse models.

\section{Smad7 and embryonic development}

The effect of Smad7 on mouse development has been revealed by manipulation of Smad7 expression through 
transgenic overexpression, virus-mediated transfection and genetic deletion by knockout technology. Overexpression of Smad7 in mouse zygotes inhibits embryonic development beyond the 2-cell stage [14]. Adenovirusinduced overexpression of Smad7 into embryonic mouse lungs in culture prevents TGF- $\beta$-mediated inhibition of both lung branching morphogenesis and epithelial cell differentiation, indicative of potential activity of Smad7 in lung development [15]. Transgenic overexpression of Smad7 in the mouse skin disrupts hair follicle morphogenesis and induces premature sebaceous gland development by antagonizing $\mathrm{Wnt} / \beta$-catenin signaling [16]. It was also reported that Smad7 inhibits chondrocyte differentiation possibly by down-regulating BMP-activated p38 mitogen-activated protein kinase (MAPK) pathways [17]. Furthermore, neural crest-restricted Smad7 overexpression leads to defects in craniofacial and cardiovascular development [18]. Collectively, while these overexpression-based studies may indicate that Smad7 has a function in early development, none of these studies could provide a definitive answer about the bona fide activity of Smad7 during early development.

Currently, there are two reported mouse models with embryonic deletion of Smad7 [19,20]. A hypomorphic Smad7 mouse model was generated by Li et al. [19], in which the exon 1 region of the Smad7 gene was deleted. These mutant mice appeared to have normal phenotypes, except for minor alterations in B-cell responses [19], likely due to the observation that the Smad7 protein deleted of the Mad-homology 1 (MH1) domain encoded by exon 1 retains the inhibitory activity on TGF- $\beta$ signaling [21]. The second Smad7 knockout model was generated by deletion of exon 4 that encodes MH2 domain of Smad7 protein and such deletion completely abolished the inhibitory activity of Smad7 on TGF- $\beta$ signaling [20]. The majority of the Smad7 mutant mice with exon 4 deletion died in utero with multiple developmental defects in the heart, including ventricular septal defect (VSD) and noncompaction of myocardium [20]. Only a small percentage of these Smad7-deficient mice could survive to adulthood, accompanied by a severe decline of cardiac functions and arrhythmia [20]. Therefore, it appears that the major effect of Smad7 on embryonic development is restricted to the cardiovascular system, especially the tissues originated from the endocardial cushion, as Smad7 was found to be highly expressed in the cushion region [22].

\section{Smad7 and fibrosis}

TGF- $\beta$ has long been considered to be a master mediator of fibrosis in many organs including the lung, kidney, pancreas, eyes, and liver. The established understanding of fibrogenesis by TGF- $\beta$ signaling is initiated by the activation of Smad-mediated pathway upon ligand binding, followed by myofibroblast transformation and stimulation of the synthesis of extracellular matrix (ECM) proteins [23]. Various fibrogenic factors have been demonstrated to participate in these processes, including type I collagen, fibronectin, laminin, and matrix metalloproteinases (MMPs). As the critical negative modulator of TGF- $\beta$ signaling, Smad7 has been proposed to play a pivotal role in the protection against TGF- $\beta$-induced fibrosis $[24,25]$.

In the mice, overexpression of Smad7 was first reported to prevent bleomycin-induced lung fibrosis in an adenovirus-mediated gene transfer model [26], suggesting that Smad7 may have applicability in the treatment of pulmonary fibrosis. During the development of unilateral ureteral obstruction (UUO) of kidneys in mice, a model of progressive tubulointerstitial fibrosis, the protein level of Smad7 was found to be progressively reduced [27]. Interestingly, the reduction of Smad7 in UUO kidneys was found to be caused by an increase in E3 ubiquitin ligase and accelerated degradation of Smad7 protein [27]. Consistently, deletion of Smad7 in the mice was found to promote renal fibrosis in UUO kidneys [28]. In addition to its effect on renal fibrosis, Smad7 has been shown to play a protective role in fibrosis in other organs. Pancreatic fibrosis is the hallmark of chronic pancreatitis, currently an incurable disease. Smad7 also possesses a protective effect on cerulein-induced pancreatic fibrosis as revealed by overexpression of Smad7 in the pancreas using an elastase promoter [29]. Furthermore, it was found that Smad7 overexpression could protect retinal pigment fibrosis in a proliferative vitreoretinopathy mouse model [30].

Fibrosis has also long been considered a leading cause of liver diseases following chronic liver injury. The final common pathway of liver fibrosis is cirrhosis, characterized by accumulation of fibrillar interstitial collagens type I and III, liver failure, and portal hypertension. Dysregulated TGF- $\beta$ signaling is implicated in chronic liver diseases [31]. In the mice, either overexpression or down-regulation of Smad7 in the liver has been used to investigate the effect of Smad7 on liver fibrosis. Ablation of TGF- $\beta$ signaling by overexpression of Smad7 specifically in hepatocytes is sufficient to blunt the fibrogenic response after tetrachloride $\left(\mathrm{CCl}_{4}\right)$ challenge and attenuate liver damage [32]. On the other hand, reduction of Smad7 expression could accelerate $\mathrm{CCl}_{4}$-induced liver damage and fibrogenesis [33]. Collectively, these studies have corroborated the protective function of Smad7 in attenuating TGF- $\beta$-mediated fibrosis in multiple organs.

\section{Smad7 in immune response and inflammation}

As TGF- $\beta$ is a critical regulator in immune and inflammation responses $[34,35]$, the potential function of 
Smad7 in immune response and inflammation has been extensively investigated. Whether Smad7 acts as an antiinflammatory factor or as a pro-inflammatory factor varies with the context of the stimulating agent, microenvironment, tissue type, and disease model.

Smad7 has been found to possess a strong anti-inflammatory effect in various studies. Smad7 is able to suppress tumor necrosis factor $\alpha$ (TNF $\alpha$ ) signaling pathway through association with TGF- $\beta$-activated kinase binding proteins (TAB2/TAB3) [36]. Consistently, transgenic expression of Smad7 in the mouse skin is able to reduce inflammatory response and nuclear factor $\kappa \mathrm{B}(\mathrm{NF} \kappa \mathrm{B})$ activation [36]. In agreement with such finding, overexpression of Smad7 in the kidney could attenuate both renal fibrosis and inflammation in a mouse model of autoimmune crescentic glomerulonephritis [37]. Smad7deficient mice developed more severe diabetic kidney injury, characterized by a significant increase in microalbuminuria, renal fibrosis and inflammation [38]. Consistently, specific deletion of Smad7 in the mouse liver enhanced inflammatory response upon alcohol administration [39].

On the other hand, Smad7 was also found to have a pro-inflammatory effect. Overexpression of Smad7 in mature $T$ cells enhances antigen-induced airway inflammation and airway reactivity [40]. Engineered CD4+ T cells with high expression of Smad7 have accelerated $\mathrm{T}$ cell proliferation and activation, resulting in severe colitis in the mouse [41]. Administration of Smad7 antisense oligonucleotide leads to prevention or reversal of inflammation in a colitis mice model induced by either trinitrobenzene sulfonic acid (TNBS) or oxazolone [42], consistent with the clinical findings that the TGF- $\beta$ signaling is impaired by elevated Smad7 expression in inflammatory bowel disease (IBD) in humans [43]. In addition, systemic administration of Smad7 antisense oligonucleotide was able to suppress inflammation in an experimental autoimmune encephalomyelitis (EAE) mouse model [44]. Consistently, transgenic overexpression of Smad7 in T cells could accelerate EAE and enhance $\mathrm{T}$ helper 1 response that was blocked by conditional deletion of Smad7 in T cells [45].

\section{Smad7 and tumorigenesis}

TGF- $\beta$ plays a dual role in cancer development, acting as a tumor suppressor in tumor initiation in an early stage but promoting tumorigenesis at a late stage by promoting epithelial-mesenchymal transition (EMT), migration, invasion and metastasis [3]. It was found that genetic polymorphisms of Smad7 are associated with human colon cancers $[46,47]$. In a chemical-induced mouse skin tumor model, Smad7 was found to be overexpressed [48]. These observations suggest that Smad7 might promote carcinogenesis in vivo. Indeed, such a notion was supported by utilizing various mice models with altered Smad7 expression levels. Overexpression of Smad7 in primary mouse keratinocytes could cooperate with oncogenic Ras to promote malignant conversion in a mouse model for squamous cell carcinoma [49]. Smad7 overexpression in the pancreas was found to induce premalignant ductal lesions [50]. Smad7 overexpression could also induce liver metastases using splenic injection of nude mice with colon adenocarcinoma (FET) cells that had overexpression of Smad7 [51]. Furthermore, overexpression of Smad7 in mouse airway epithelium under the control of a mouse Clara cell specific $10 \mathrm{kDa}$ protein $(\mathrm{CC} 10)$ promoter could promote formation of lung cancer formation upon urethane treatment [52]. Collectively, these studies indicate that Smad7 has a tumor-promoting function, most likely due to its inhibitory effect on the tumor suppressor activity of TGF- $\beta$.

Interestingly, Smad7 has also been reported to inhibit tumor formation and metastasis as revealed by various studies. Overexpression of Smad7 in breast cancer cells led to reduction in metastasis and improvement of survival in tumor-bearing mice [53]. In a human melanoma cell lines, ectopic expression of Smad7 was able to reduce tumorigenesis as analyzed by xenograft experiment in nude mice [54]. More recently, it was found that overexpression of Smad7 in T cells was able to suppress colitis-associated tumors in the mice, accompanied by elevated expression of interferon- $\gamma$ (IFN $\gamma$ ) and accumulation of cytotoxic CD8+ and Natural Killer (NK) T cells in the tumors and peritumoral areas [55]. These studies, therefore, have pinpointed a complex role of Smad7 in tumorigenesis.

\section{Smad7 in epithelium}

The physiological functions of Smad7 in the skin have been demonstrated by a number of studies. Keratin $\mathrm{K} 5$ promoter-induced overexpression of Smad7 specifically in mouse epidermis shows multiple epithelial and developmental abnormalities at birth, exhibited as corneal defects in the eyes, aberrant hair follicle morphogenesis in the skin, epidermal hyperproliferation in the digestive tract and severe thymic atrophy $[16,56]$. The epithelial hyperplasia arisen in these Smad7 transgenic mice might be contributed to increased cell proliferation and aberrant apoptosis. Another mechanistic possibility could be dysregulation of $\mathrm{Wnt} / \beta$-catenin signaling, as Smad7 was revealed to antagonize $\mathrm{Wnt} / \beta$-catenin signaling by accelerating $\beta$-catenin degradation such that skin differentiation was shifted from forming hair follicles to sebaceous glands [16]. In addition, transgenic expression of Smad7 in the mouse skin could reduce inflammatory response and $\mathrm{NF} \kappa \mathrm{B}$ activation [36]. Collectively, these studies reveal that Smad7 plays an 
important role in the differentiation, fibrosis and inflammatory response of the epithelium.

\section{Smad7 in metabolism}

It was recently discovered that Smad7 plays an important role in $\beta$-cells, the insulin secreting cells in the pancreatic islets [57]. Conditional overexpression of Smad7 under the promoter of $\mathrm{Pdx} 1$, a gene that is specifically expressed in pancreatic progenitor cells as well as in adult $\beta$ cells, could disrupt endocrine cell differentiation in embryonic stage and cause overt diabetes when Smad7 was conditionally induced in adult $\beta$-cells [57]. This study indicates that TGF- $\beta$ signaling is critical for homeostasis of adult $\beta$-cell functions, as the reduction in insulin secretion and hyperglycemia caused by Smad7 overexpression could be rescued by restoration of TGF$\beta$ signaling in the $\beta$-cells [57]. In a streptozotocininduced diabetic mouse model, deletion of Smad7 could accelerate diabetic renal injury, likely caused by increases in TGF- $\beta$ signaling and NF- $\kappa \mathrm{B}$-mediated signaling pathway [38]. Consistently, overexpression of Smad7 in diabetic rats could attenuate renal fibrosis and inflammation [38]. Furthermore, hepatic deficiency of Smad7 in the mice accelerates alcohol-induced liver steatosis, likely caused by blunting of ethanol-induced production of alcohol dehydrogenase 1 (ADH1) and upregulation of critical genes involved in lipogenesis [39]. Collectively, these studies indicate that Smad7 may have a functional role in metabolic control.

\section{Conclusions and perspectives}

In the past decades, the physiological roles of Smad7 have been elucidated by using different mouse models with either overexpression or deletion of Smad7 in different tissues/organs (Table 1). These studies have pinpointed various functions of Smad7 in a large array of

Table 1 Overview of mouse studies with altered expression of Smad7

\begin{tabular}{|c|c|c|c|c|c|}
\hline $\begin{array}{l}\text { Organ } \\
\text { (Tissue) }\end{array}$ & $\begin{array}{l}\text { Modification } \\
\text { of Smad7 }\end{array}$ & Functions or phenotypes & Proposed mechanisms & Related disease(s) & Ref \\
\hline Zygote & Overexpression & $\begin{array}{l}\text { The embryos do not develop beyond 2-cell } \\
\text { stage }\end{array}$ & $\begin{array}{l}\text { Inhibiting TGF- } \beta \text { and BMP } \\
\text { signaling }\end{array}$ & none & {$[14]$} \\
\hline Lung & Overexpression & $\begin{array}{l}\text { Anti-fibrosis, anti-inflammation, tumorigenic, } \\
\text { involved in lung branching morphogenesis } \\
\text { and epithelial differentiation }\end{array}$ & $\begin{array}{l}\text { Blocking synthesis of ECM, } \\
\text { preventing NF } \kappa \text { B activation and } \\
\text { inhibiting EMT }\end{array}$ & $\begin{array}{l}\text { Lung fibrosis, } \\
\text { neonatal hyperoxia, } \\
\text { allergic asthma and } \\
\text { lung cancer }\end{array}$ & {$[15,26,52]$} \\
\hline Eyes & Overexpression & $\begin{array}{l}\text { Anti-fibrosis, anti-inflammation, and improving } \\
\text { healing from chemical burn injury }\end{array}$ & $\begin{array}{l}\text { Blocking EMT and accelerating } \\
\text { healing after injury }\end{array}$ & $\begin{array}{l}\text { Retinal pigment } \\
\text { fibrosis }\end{array}$ & {$[30,58,59]$} \\
\hline Skin & Overexpression & $\begin{array}{l}\text { Shifting skin differentiation from hair follicles } \\
\text { to sebaceous glands, accelerating squamous } \\
\text { cell carcinogenesis, tumorigenic, anti- } \\
\text { inflammation }\end{array}$ & $\begin{array}{l}\text { Suppressing Wnt/ } \beta \text {-catenin } \\
\text { signaling, inducing EGF-like } \\
\text { growth factors expression, } \\
\text { blocking NF } \kappa B \text { signaling }\end{array}$ & $\begin{array}{l}\text { Scleroderma, skin } \\
\text { cancer, inflammation }\end{array}$ & {$[16,36,49,56]$} \\
\hline Liver & $\begin{array}{l}\text { Overexpression } \\
\text { Knockout }\end{array}$ & $\begin{array}{l}\text { Anti-fibrosis, anti-inflammation, inhibiting EMT } \\
\text { and apoptosis, reducing alcoholic liver injury }\end{array}$ & $\begin{array}{l}\text { Blocking ECM production, anti- } \\
\text { oxidative stress, activating } \\
\text { ADH1, suppressing alcoholic } \\
\text { steatosis }\end{array}$ & $\begin{array}{l}\text { Liver fibrosis, cirrhosis, } \\
\text { alcoholic fatty liver }\end{array}$ & {$[32,33,39]$} \\
\hline Pancreas & Overexpression & $\begin{array}{l}\text { Abolishing } \beta \text {-cell differentiation in embryo, } \\
\text { inhibiting insulin secretion in adults, anti- } \\
\text { fibrosis, inducing early tumorigenesis }\end{array}$ & $\begin{array}{l}\text { Inhibiting TGF- } \beta \text { signaling, pro- } \\
\text { proliferative }\end{array}$ & $\begin{array}{l}\text { Pancreatic fibrosis, } \\
\text { pancreatitis, } \\
\text { pancreatic cancer, } \\
\text { diabetes }\end{array}$ & {$[29,50,57]$} \\
\hline Kidney & $\begin{array}{l}\text { Overexpression } \\
\text { Knockout }\end{array}$ & $\begin{array}{l}\text { Anti-fibrosis, anti-inflammation, protecting } \\
\text { against diabetic injury }\end{array}$ & $\begin{array}{l}\text { Reducing ECM accumulation, } \\
\text { blocking } N F \kappa B \text { signaling }\end{array}$ & $\begin{array}{l}\text { Nephritis, kidney } \\
\text { fibrosis, diabetic } \\
\text { kidney injury }\end{array}$ & {$[27,28,37,38]$} \\
\hline Colon & $\begin{array}{l}\text { Overexpression } \\
\text { Knockdown }\end{array}$ & $\begin{array}{l}\text { Enhancing inflammatory reaction, increasing } \\
\text { cancer metastasis }\end{array}$ & $\begin{array}{l}\text { CD4+ T cell overactivation and } \\
\text { resistance to regulatory } T \text { cell, } \\
\text { reduced growth inhibition and } \\
\text { apoptosis }\end{array}$ & $\begin{array}{l}\text { IBD, colitis, colorectal } \\
\text { cancer }\end{array}$ & {$[42,51]$} \\
\hline CNS & $\begin{array}{l}\text { Overexpression } \\
\text { Knockdown }\end{array}$ & $\begin{array}{l}\text { Pro-inflammatory, craniofacial and cardiac } \\
\text { defects }\end{array}$ & $\begin{array}{l}\text { Promoting T cell activation, } \\
\text { blocking Wnt, BMP and TGF- } \beta \\
\text { signaling }\end{array}$ & $\begin{array}{l}\text { Autoimmune } \\
\text { encephalomyelitis, } \\
\text { craniofacial defects }\end{array}$ & {$[18,44]$} \\
\hline $\begin{array}{l}\text { Immune } \\
\text { cells }\end{array}$ & $\begin{array}{l}\text { Overexpression } \\
\text { Knockout }\end{array}$ & $\begin{array}{l}\text { Involved in proliferation of } \mathrm{T} \text { cell and B cell } \\
\text { response to antigen stimulation, pro- } \\
\text { inflammatory, tumor suppression }\end{array}$ & $\begin{array}{l}\text { Involved in immune cell } \\
\text { maturation, proliferation and } \\
\text { activation }\end{array}$ & $\begin{array}{l}\text { Allergic asthma, } \\
\text { autoimmune disorder, } \\
\text { colitis, colon cancer }\end{array}$ & {$[19,40,41,45,55]$} \\
\hline Bone & Overexpression & Inhibiting chondrocyte differentiation & $\begin{array}{l}\text { Down-regulating p38 MAPK } \\
\text { pathway }\end{array}$ & $\begin{array}{l}\text { Joint disease and } \\
\text { repair }\end{array}$ & {$[17]$} \\
\hline Systemic & Knockout & $\begin{array}{l}\text { Important for early heart development and B } \\
\text { cell function }\end{array}$ & $\begin{array}{l}\text { Apoptosis, inhibiting TGF- } \beta \\
\text { signaling }\end{array}$ & $\begin{array}{l}\text { Congenital heart } \\
\text { defects }\end{array}$ & {$[19,20]$} \\
\hline
\end{tabular}


biological processes including early embryonic development, fibrosis of many organs, skin cell differentiation, regulation of immune response and inflammation, tumorigenesis, and metabolic control (Table 1). A few conclusions could be drawn based on these in vivo studies. Firstly, it appears that a balanced expression level of Smad7 is necessary for maintaining homeostasis during embryonic development and for proper functionality of many organs. For example, dysregulated Smad7 expression may cause severe developmental defects in cardiovascular morphogenesis, lung branching, hair follicle morphogenesis, and eye development. Secondly, the major convincing evidence in terms of using overexpression of Smad7 as a potential therapy is the protective roles of Smad7 on fibrotic damage through blocking TGF- $\beta$-induced ECM production. Thirdly, the roles of Smad7 in the regulation of immune response and inflammation vary depending on the type of tissues/cells and the nature of inflammatory stimuli. Fourthly, the function of Smad7 on tumorigenesis is complex, dependent on the tumor type and model system used in the study. Whether Smad7 has a definitive role in tumor progression and metastasis awaits application of more sophisticated mouse models focused on analyzing latestage tumor development. Finally, it is noteworthy that Smad7 may have other important physiological functions yet to be discovered, such as its roles in different facets of metabolic control. With the advances of cutting-edge technology, it is anticipated that Smad7 will continue to be an intriguing molecule that will be vigorously investigated in the future, especially considering its close relevance to human diseases.

\section{Acknowledgements \\ This work was supported by research grants from National Natural Science Foundation of China (30830037 and 81021002) to YC.}

\section{Authors' contributions}

LZ, SC and YC wrote the paper. All authors read and approved the final manuscript.

\section{Authors information}

Susie Chen was a summer student from University of Washington at Seattle.

\section{Competing interests}

None of the authors had any financial and personal relationships with other people or organisations that could inappropriately influence (bias) their work.

Received: 9 October 2011 Accepted: 28 December 2011 Published: 28 December 2011

\section{References}

1. Massague J: TGF-beta signal transduction. Annu Rev Biochem 1998, 67:753-791.

2. Shi Y, Massague J: Mechanisms of TGF-beta signaling from cell membrane to the nucleus. Cell 2003, 113:685-700.

3. Massague J: TGFbeta in Cancer. Cell 2008, 134:215-230.
4. Imamura T, Takase M, Nishihara A, Oeda E, Hanai J, Kawabata M, Miyazono K: Smad6 inhibits signalling by the TGF-beta superfamily. Nature 1997, 389:622-626.

5. Nakao A, Afrakhte M, Moren A, Nakayama T, Christian JL, Heuchel R, Itoh S, Kawabata M, Heldin NE, Heldin CH, ten Dijke P: Identification of Smad7, a TGFbeta-inducible antagonist of TGF-beta signalling. Nature 1997, 389:631-635.

6. Casellas R, Brivanlou AH: Xenopus Smad7 inhibits both the activin and BMP pathways and acts as a neural inducer. Dev Biol 1998, 198:1-12

7. Hayashi H, Abdollah S, Qiu Y, Cai J, Xu YY, Grinnell BW, Richardson MA, Topper JN, Gimbrone MA, Wrana JL, Falb D: The MAD-related protein Smad7 associates with the TGFbeta receptor and functions as an antagonist of TGFbeta signaling. Cell 1997, 89:1165-1173.

8. Lebrun JJ, Takabe K, Chen Y, Vale W: Roles of pathway-specific and inhibitory Smads in activin receptor signaling. Mol Endo 1999, 13:15-23.

9. Kavsak P, Rasmussen RK, Causing CG, Bonni S, Zhu H, Thomsen GH, Wrana JL: Smad7 binds to Smurf2 to form an E3 ubiquitin ligase that targets the TGF beta receptor for degradation. Mol Cell 2000, 6:1365-1375.

10. Ebisawa T, Fukuchi M, Murakami G, Chiba T, Tanaka K, Imamura T, Miyazono K: Smurf1 interacts with transforming growth factor-beta type I receptor through Smad7 and induces receptor degradation. J Biol Chem 2001, 276:12477-12480.

11. Suzuki C, Murakami G, Fukuchi M, Shimanuki T, Shikauchi Y, Imamura T, Miyazono K: Smurf1 regulates the inhibitory activity of Smad7 by targeting Smad7 to the plasma membrane. J Biol Chem 2002, 277:39919-39925.

12. Shi W, Sun C, He B, Xiong W, Shi X, Yao D, Cao X: GADD34-PP1c recruited by Smad7 dephosphorylates TGFbeta type I receptor. J Cell Biol 2004, 164:291-300.

13. Yan $X$, Chen YG: Smad7: not only a regulator, but also a cross-talk mediator of TGF-beta signalling. Biochem J 2011, 434:1-10.

14. Zwijsen A, van Rooijen MA, Goumans MJ, Dewulf N, Bosman EA, ten Dijke P, Mummery CL, Huylebroeck D: Expression of the inhibitory Smad7 in early mouse development and upregulation during embryonic vasculogenesis. Dev Dyn 2000, 218:663-670.

15. Zhao J, Shi W, Chen H, Warburton D: Smad7 and Smad6 differentially modulate transforming growth factor beta -induced inhibition of embryonic lung morphogenesis. J Biol Chem 2000, 275:23992-23997.

16. Han G, Li AG, Liang YY, Owens P, He W, Lu S, Yoshimatsu Y, Wang D, Ten Dijke $P$, Lin $X$, Wang XJ: Smad7-induced beta-catenin degradation alters epidermal appendage development. Dev Cell 2006, 11:301-312.

17. Iwai T, Murai J, Yoshikawa H, Tsumaki N: Smad7 Inhibits chondrocyte differentiation at multiple steps during endochondral bone formation and down-regulates p38 MAPK pathways. J Biol Chem 2008, 283:27154-27164.

18. Tang S, Snider P, Firulli AB, Conway SJ: Trigenic neural crest-restricted Smad7 over-expression results in congenital craniofacial and cardiovascular defects. Dev Biol 2010, 344:233-247.

19. Li R, Rosendahl A, Brodin G, Cheng AM, Ahgren A, Sundquist C, Kulkarni S, Pawson T, Heldin $\mathrm{CH}$, Heuchel RL: Deletion of exon I of SMAD7 in mice results in altered $B$ cell responses. J Immunol 2006, 176:6777-6784.

20. Chen Q, Chen H, Zheng D, Kuang C, Fang H, Zou B, Zhu W, Bu G, Jin T, Wang Z, et al: Smad7 is required for the development and function of the heart. J Biol Chem 2009, 284:292-300.

21. Mochizuki T, Miyazaki H, Hara T, Furuya T, Imamura T, Watabe T, Miyazono K: Roles for the $\mathrm{MH} 2$ domain of Smad7 in the specific inhibition of transforming growth factor-beta superfamily signaling. $J$ Biol Chem 2004, 279:31568-31574.

22. Liu X, Chen Q, Kuang C, Zhang M, Ruan Y, Xu ZC, Wang Z, Chen Y: A 4.3 $\mathrm{kb}$ Smad7 promoter is able to specify gene expression during mouse development. Biochim Biophys Acta 2007, 1769:149-152.

23. Wynn TA: Common and unique mechanisms regulate fibrosis in various fibroproliferative diseases. J Clin Invest 2007, 117:524-529.

24. Dooley S, Hamzavi J, Breitkopf K, Wiercinska E, Said HM, Lorenzen J, Ten Dijke P, Gressner AM: Smad7 prevents activation of hepatic stellate cells and liver fibrosis in rats. Gastroenterology 2003, 125:178-191.

25. Wang W, Koka V, Lan HY: Transforming growth factor-beta and Smad signalling in kidney diseases. Nephrology 2005, 10:48-56.

26. Nakao A, Fujii M, Matsumura R, Kumano K, Saito Y, Miyazono K, Iwamoto I: Transient gene transfer and expression of Smad7 prevents bleomycininduced lung fibrosis in mice. J Clin Invest 1999, 104:5-11. 
27. Fukasawa H, Yamamoto T, Togawa A, Ohashi N, Fujigaki Y, Oda T, Uchida C, Kitagawa K, Hattori T, Suzuki S, et al: Down-regulation of Smad7 expression by ubiquitin-dependent degradation contributes to renal fibrosis in obstructive nephropathy in mice. Proc Natl Acad Sci USA 2004, 101:8687-8692.

28. Chung AC, Huang XR, Zhou L, Heuchel R, Lai KN, Lan HY: Disruption of the Smad7 gene promotes renal fibrosis and inflammation in unilateral ureteral obstruction (UUO) in mice. Nephrol Dial Transplant 2009, 24:1443-1454.

29. He J, Sun X, Qian KQ, Liu X, Wang Z, Chen Y: Protection of ceruleininduced pancreatic fibrosis by pancreas-specific expression of Smad7. Biochim Biophys Acta 2009, 1792:56-60.

30. Saika S, Yamanaka O, Nishikawa-Ishida I, Kitano A, Flanders KC, Okada Y, Ohnishi Y, Nakajima Y, Ikeda K: Effect of Smad7 gene overexpression on transforming growth factor beta-induced retinal pigment fibrosis in a proliferative vitreoretinopathy mouse model. Arch Ophthalmol 2007, 125:647-654.

31. Bataller R, Brenner DA: Liver fibrosis. J Clin Invest 2005, 115:209-218.

32. Dooley S, Hamzavi J, Ciuclan L, Godoy P, Ilkavets I, Ehnert S, Ueberham E, Gebhardt R, Kanzler S, Geier A, et al: Hepatocyte-specific Smad7 expression attenuates TGF-beta-mediated fibrogenesis and protects against liver damage. Gastroenterology 2008, 135:642-659.

33. Hamzavi J, Ehnert S, Godoy P, Ciuclan L, Weng H, Mertens PR, Heuchel R, Dooley S: Disruption of the Smad7 gene enhances CCl4-dependent liver damage and fibrogenesis in mice. J Cell Mol Med 2008, 12:2130-2144.

34. Letterio JJ, Roberts AB: Regulation of immune responses by TGF-beta. Annu Rev Immunol 1998, 16:137-161.

35. Li MO, Wan YY, Sanjabi S, Robertson AK, Flavell RA: Transforming growth factor-beta regulation of immune responses. Annu Rev Immunol 2006, 24:99-146.

36. Hong S, Lim S, Li AG, Lee C, Lee YS, Lee EK, Park SH, Wang XJ, Kim SJ: Smad7 binds to the adaptors TAB2 and TAB3 to block recruitment of the kinase TAK1 to the adaptor TRAF2. Nat Immunol 2007, 8:504-513.

37. Ka SM, Huang XR, Lan HY, Tsai PY, Yang SM, Shui HA, Chen A: Smad7 gene therapy ameliorates an autoimmune crescentic glomerulonephritis in mice. J Am Soc Nephrol 2007, 18:1777-1788.

38. Chen HY, Huang XR, Wang W, Li JH, Heuchel RL, Chung AC, Lan HY: The protective role of Smad7 in diabetic kidney disease: mechanism and therapeutic potential. Diabetes 2011, 60:590-601.

39. Zhu L, Wang L, Wang X, Luo X, Yang L, Zhang R, Yin H, Xie D, Pan Y, Chen $Y$ : Hepatic deletion of Smad7 in mouse leads to spontaneous liver dysfunction and aggravates alcoholic liver injury. PLoS One 2011, 6: e17415.

40. Nakao A, Miike S, Hatano M, Okumura K, Tokuhisa T, Ra C, Iwamoto I: Blockade of transforming growth factor beta/Smad signaling in $T$ cells by overexpression of Smad7 enhances antigen-induced airway inflammation and airway reactivity. J Exp Med 2000, 192:151-158.

41. Fantini MC, Rizzo A, Fina D, Caruso R, Sarra M, Stolfi C, Becker C, Macdonald TT, Pallone F, Neurath MF, Monteleone G: Smad7 controls resistance of colitogenic $\mathrm{T}$ cells to regulatory $\mathrm{T}$ cell-mediated suppression. Gastroenterology 2009, 136:1308-1316, e1301-1303.

42. Boirivant M, Pallone F, Di Giacinto C, Fina D, Monteleone I, Marinaro M, Caruso R, Colantoni A, Palmieri G, Sanchez M, et al: Inhibition of Smad7 with a specific antisense oligonucleotide facilitates TGF-beta1-mediated suppression of colitis. Gastroenterology 2006, 131:1786-1798.

43. Monteleone G, Kumberova A, Croft NM, McKenzie C, Steer HW, MacDonald TT: Blocking Smad7 restores TGF-beta1 signaling in chronic inflammatory bowel disease. J Clin Invest 2001, 108:601-609.

44. Kleiter I, Pedre X, Mueller AM, Poeschl P, Couillard-Despres S, Spruss T, Bogdahn U, Giegerich G, Steinbrecher A: Inhibition of Smad7, a negative regulator of TGF-beta signaling, suppresses autoimmune encephalomyelitis. J Neuroimmunol 2007, 187:61-73.

45. Kleiter I, Song J, Lukas D, Hasan M, Neumann B, Croxford AL, Pedre X, Hovelmeyer N, Yogev N, Mildner A, et al: Smad7 in T cells drives T helper 1 responses in multiple sclerosis and experimental autoimmune encephalomyelitis. Brain 2010, 133:1067-1081.

46. Thompson CL, Plummer SJ, Acheson LS, Tucker TC, Casey G, Li L: Association of common genetic variants in SMAD7 and risk of colon cancer. Carcinogenesis 2009, 30:982-986.
47. Slattery ML, Herrick J, Curtin K, Samowitz W, Wolff RK, Caan BJ, Duggan D, Potter JD, Peters U: Increased risk of colon cancer associated with a genetic polymorphism of SMAD7. Cancer Res 2010, 70:1479-1485.

48. He W, Cao T, Smith DA, Myers TE, Wang XJ: Smads mediate signaling of the TGFbeta superfamily in normal keratinocytes but are lost during skin chemical carcinogenesis. Oncogene 2001, 20:471-483.

49. Liu X, Lee J, Cooley M, Bhogte E, Hartley S, Glick A: Smad7 but not Smad6 cooperates with oncogenic ras to cause malignant conversion in a mouse model for squamous cell carcinoma. Cancer Res 2003, 63:7760-7768.

50. Kuang C, Xiao Y, Liu X, Stringfield TM, Zhang S, Wang Z, Chen Y: In vivo disruption of TGF-beta signaling by Smad7 leads to premalignant ductal lesions in the pancreas. Proc Natl Acad Sci USA 2006, 103:1858-1863.

51. Halder SK, Rachakonda G, Deane NG, Datta PK: Smad7 induces hepatic metastasis in colorectal cancer. $\mathrm{Br} J$ Cancer 2008, 99:957-965.

52. Luo X, Ding Q, Wang M, Li Z, Mao K, Sun B, Pan Y, Wang Z, Zang YQ, Chen $Y$ : In vivo disruption of TGF-beta signaling by Smad7 in airway epithelium alleviates allergic asthma but aggravates lung carcinogenesis in mouse. PLoS One 2010, 5:e10149.

53. Azuma $H$, Ehata $S$, Miyazaki $H$, Watabe $T$, Maruyama $O$, Imamura $T$, Sakamoto T, Kiyama S, Kiyama Y, Ubai T, et al: Effect of Smad7 expression on metastasis of mouse mammary carcinoma JygMC(A) cells. J Natl Cancer / 2005, 97:1734-1746.

54. Javelaud D, Delmas V, Moller M, Sextius P, Andre J, Menashi S, Larue L, Mauviel A: Stable overexpression of Smad7 in human melanoma cells inhibits their tumorigenicity in vitro and in vivo. Oncogene 2005, 24:7624-7629.

55. Rizzo A, Waldner MJ, Stolfi C, Sarra M, Fina D, Becker C, Neurath MF, Macdonald TT, Pallone F, Monteleone G, Fantini MC: Smad7 expression in T cells prevents colitis-associated cancer. Cancer Res 2011.

56. He W, Li AG, Wang D, Han S, Zheng B, Goumans MJ, Ten Dijke P, Wang XJ: Overexpression of Smad7 results in severe pathological alterations in multiple epithelial tissues. EMBO J 2002, 21:2580-2590.

57. Smart NG, Apelqvist AA, Gu X, Harmon EB, Topper JN, MacDonald RJ, Kim SK: Conditional expression of Smad7 in pancreatic beta cells disrupts TGF-beta signaling and induces reversible diabetes mellitus. PLoS Biol 2006, 4:e39.

58. Saika S, Ikeda K, Yamanaka O, Sato M, Muragaki $Y$, Ohnishi $Y$, Ooshima A, Nakajima Y, Namikawa K, Kiyama $H$, et al: Transient adenoviral gene transfer of Smad7 prevents injury-induced epithelial-mesenchymal transition of lens epithelium in mice. Lab Invest 2004, 84:1259-1270.

59. Saika S, Ikeda K, Yamanaka O, Miyamoto T, Ohnishi Y, Sato M, Muragaki Y, Ooshima A, Nakajima Y, Kao WW, et al: Expression of Smad7 in mouse eyes accelerates healing of corneal tissue after exposure to alkali. Am J Pathol 2005, 166:1405-1418.

doi:10.1186/2045-3701-1-44

Cite this article as: Zhu et al:: Unraveling the biological functions of Smad7 with mouse models. Cell \& Bioscience 2011 1:44.

\section{Submit your next manuscript to BioMed Central and take full advantage of:}

- Convenient online submission

- Thorough peer review

- No space constraints or color figure charges

- Immediate publication on acceptance

- Inclusion in PubMed, CAS, Scopus and Google Scholar

- Research which is freely available for redistribution

Submit your manuscript at www.biomedcentral.com/submit
C Biomed Central 